\title{
Antimicrobial Susceptibility Testing and Phenotypic Detection of MRSA Isolated from Diabetic Foot Infection
}

This article was published in the following Dove Press journal: International Journal of General Medicine

\author{
Khanda Anwar' \\ Dlsoz Hussein (iD) ${ }^{2}$ \\ Jamal Salih ${ }^{3,4}$ \\ 'Microbiology Department, College of \\ Medicine, University of Sulaimani, \\ Sulaymaniyah, Kurdistan Region, Iraq; \\ ${ }^{2}$ Microbiology Department, Central \\ Public Health Laboratory I, \\ Sulaymaniyah, Kurdistan Region, Iraq; \\ ${ }^{3}$ Physiology Department, College of \\ Medicine, University of Sulaimani, \\ Sulaymaniyah, Kurdistan Region, Iraq; \\ ${ }^{4}$ Diabetes and Endocrine Centre, \\ Sulaymaniyah, Iraq
}

Background: Diabetic foot infection (DFI) is a common and costly complication of diabetes that may be caused by various bacteria with multi-resistant genes. The aim of this study is to evaluate the efficacy of phenotypic methods for identification of methicillinresistant Staphylococcus aureus (MRSA) with genotypic detection of MRSA-related genes. Methods: In this cross-sectional study, swab samples were collected from patients with DFI from hospitals in Sulaimani/Iraq in April-July 2019. All the samples were processed for microbiological assessment and further MRSA phenotypic and genotypic testing.

Results: A total of 46 swab samples were collected from diabetic foot ulcers of 29 males and 17 females. Most samples (93.5\%) showed positive growth, with higher proportions of monomicrobial $(23 ; 53.5 \%)$ than mixed-bacterial infections $(20 ; 46.5 \%)$ and $S$. aureus as the predominant pathogen. Conventional methods of MRSA detection, such as cefoxitin disc diffusion, can predict methicillin resistance in $45.8 \%$ of the cases. Real-time/conventional PCR showed that $41.6 \%$ of Staphylococcus aureus were positive for the mecA gene, while none of the isolates was positive for $P V L$.

Conclusion: Staphylococcus aureus was the predominant pathogen in DFI. Although cefoxitin and oxacillin disc diffusion methods can help in the prediction of MRSA, realtime PCR is a reliable method for MRSA detection and confirmation.

Keywords: diabetic foot, infection, MRSA, genotypic detection

\section{Introduction}

Diabetes mellitus is a common chronic disease, characterized by persistent hyperglycemia. One of the most serious complications of this disease is diabetic foot infection (DFI), ${ }^{1}$ which is caused by single or multiple microorganisms. ${ }^{2}$ Aerobic Gram-positive cocci, such as Staphylococcus aureus, are the predominant organism responsible for acute DFI. However, polymicrobial isolates are mostly observed in chronic wound infections. Numerous studies have reported that DFI was caused by multidrug-resistant organisms, such as extended-spectrum $\beta$-lactamase producing Gram-negative rods and Methicillin-resistant Staphylococcus aureus (MRSA).,

The presence of MRSA strains is focused on the presence of $m e c A$, which determines the synthesis of abnormal penicillin-binding proteins (PBPs). These PBPs normally have a strong affinity for the $\beta$-lactam ring $^{5}$; however, in the strains of MRSA, another PBP2a has a very low affinity for binding to the $\beta$-lactam antibiotics. This leads to the methicillin antibiotics failing to destroy the bacterial cell wall. ${ }^{6}$
Physiology Department, College of Medicine, University of Sulaimani, New-Street-27, Zone 209, P.O. Box: 334

Sulaimaniyah, Kurdistan Region, Iraq Tel +00964-7702441985

Email jamal.salih@univsul.edu.iq
International Journal of General Medicine 2020:13 I349-1357 
MRSA detection commonly depends on a combination of disc diffusion and molecular methods. The phenotypic (cefoxitin and oxacillin disc diffusion) method is commonly used, whereas the genotypic method for detecting $m e c A$ is highly conserved to MRSA. Additionally, PantonValentine leukocidin $(P V L)$, which is a cytolytic toxin produced by less than $5 \%$ of $S$. aureus strains, is regarded as a virulence factor; however, its role in DFI remains controversial. $^{7}$ Since the phenotypic method is widely available, it remains the method of choice, but phenotypic method is time-consuming, and the strain detection can be affected by environmental factors. Therefore, detection of the mec $A$ gene and penicillin-binding proteins by molecular techniques is considered for MRSA confirmation. ${ }^{8}$

Treatment of MRSA infections is a global challenge. Nowadays, MRSA provides resistance to the previously effective $\beta$-lactam antibiotics. ${ }^{9}$ Glycopeptides inhibit bacterial cell wall synthesis using a different mechanism to that of the $\beta$-lactams, so they are potentially active against all $S$. aureus strains, including MRSA. $^{10}$ Vancomycin and teicoplanin are highly effective in treatment of serious MRSA infections; however, the suboptimal response often necessitates the addition of a second or third antimicrobial agent, such as rifampicin and aminoglycosides. ${ }^{11,12}$ Reasonable empirical antibiotic treatments in limb-threatening infections include a combination of an anti-anaerobic agent like clindamycin and an anti-aerobic antibiotic. ${ }^{13}$ Over the past few years, new cephalosporins with improved activity against Staphylococcus aureus have been discovered; however, their antimicrobial activities are insufficient to eradicate MRSA infection, ${ }^{14}$ except for the fourth generation parenteral cephalosporin, which has shown good antibacterial activity against MRSA.

In our locality, data on DFI are lacking, and there is neither a sufficiency of published studies nor consistent practical, evidence-based guidance to suggest appropriate antibiotic choices based on local data. The aim of this study is to evaluate the efficacy of phenotypic methods for identification of MRSA. An additional aim was genotypic detection of MRSA-related genes (mecA and $P V L$ ).

\section{Methodology}

This study was conducted in different hospitals in Sulaimani and ethical approval was obtained from the Directorate of Health in Sulaimani. This cross-sectional study included 46 patients with type II diabetes mellitus presented with DFI in Diabet Center, Shar Hospital and Surgical Teaching Hospital in Sulaimani from April to July 2019. This study was conducted in accordance with the Declaration of Helsinki and signed informed consent was obtained from all patients before enrollment. The swab samples were selected according to the presence of signs and symptoms of foot infection. ${ }^{13}$ The subjects were classified into two groups ("hospitalized" and "community"), based on admission time to the hospital: patients who had been seen in outpatient clinics and admitted to hospitals within 48 hours were classified as nonhospitalized (community group) patients, while those who stayed in hospital for more than 48 hours were recorded as hospitalized patients. ${ }^{15}$ From each patient, random blood sugar, $\mathrm{HbA1c}$, and demographic data such as age, gender, smoking, and alcoholic status were obtained.

All DFI wounds were selected to be tested by taking swabs. ${ }^{16}$ The swabs were promptly delivered to the microbiology laboratory in Emergency and Plastic Surgery Hospital in Sulaimani within 2 hours from collection or stored at $4^{\circ} \mathrm{C}$ for 4 hours; subsequently, the samples were processed $^{17}$ by routine standard culture techniques and prompt identification and freezing of the samples for molecular work. ${ }^{18}$ Antibiotic susceptibility testing was done by the Kirby-Bauer disc diffusion method, in accordance with the guidelines of the National Committee for the Clinical Laboratory Standards Institute (CLSI). ${ }^{19}$

\section{Phenotypic Detection of MRSA}

All isolated $S$. aureus strains were tested by oxacillin and cefoxitin disc diffusion methods, according to what was described previously. ${ }^{19}$

\section{Genotypic Detection of MRSA}

Two genes (mecA and $P V L$ ) were selected in this study to be analyzed by molecular techniques. Bacterial reactivation $^{18}$ and DNA extraction were performed on all isolated coagulase-positive $S$. aureus strains (MRSA and MSSA) according to the recommendation of the manufacturers of the Automated DNA extraction kit (MagCore ${ }^{\mathbb{B}}$ Nucleic Acid Extraction Kit RBC bioscienceTaiwan).

Two sets of primers were used in this study, designed by Macrogen/Korea, both forward and reverse (Table 1), according to what was previously tested by Bhatta et al (2016). Main stock primers $(100 \mathrm{pmol} / \mu \mathrm{L})$ were prepared by suspending each primer (forward and reverse) in free DNA and RNA injection water (for mecAl and mecA2 oligonucleotide by adding $300 \mu \mathrm{L}$, for LUK- $P V-1270 \mu \mathrm{L}$, and for LUK- $P V-2290 \mu \mathrm{L}$ ), according to what was 
Table I Primer (mecA, PVL) Gene Oligonucleotide Sequence

\begin{tabular}{|l|l|l|l|}
\hline Gene Name & Nucleotides & Base Pair Size & References \\
\hline $\begin{array}{l}\text { mecA-I } \\
\text { meAA-2 }\end{array}$ & $\begin{array}{l}\text { 5-GTA GAA ATG ACT GAA CGT CCG ATA A-3 } \\
\text { 5- CCA ATT CCA CAT TGT TTC GGT CTA-3 }\end{array}$ & 310 bp \\
\hline $\begin{array}{l}\text { LUK-PV-I } \\
\text { LUK-PV-2 }\end{array}$ & $\begin{array}{l}\text { ATC ATT AGG TAA AAT GTC TGG ACA TGA TCC A } \\
\text { GCA TCA AGT GTA TTG GAT AGC AAA AGC }\end{array}$ & 433 bP & 21 \\
\hline
\end{tabular}

Table 2 Real-Time PCR Conditions

\begin{tabular}{|c|c|c|c|c|c|c|}
\hline Gene Cycles & Initial Denaturation & Denaturation & Annealing & Extension & Final Extensio & \\
\hline Time and temperature mecA & $94^{\circ} \mathrm{C} / 4$ minutes & $94^{\circ} \mathrm{C} / 30$ seconds & $60^{\circ} \mathrm{C} / 30$ seconds & $72^{\circ} \mathrm{C} / 30$ seconds & $72^{\circ} \mathrm{C} / 5$ minutes & 30 \\
\hline Time and temperature $P V L$ & $94{ }^{\circ} \mathrm{C} / 4$ minutes & $94^{\circ} \mathrm{C} / 40$ seconds & $58^{\circ} \mathrm{C} / 30$ seconds & $72^{\circ} \mathrm{C} / 30$ seconds & $72^{\circ} \mathrm{C} / 5$ minutes & 30 \\
\hline
\end{tabular}

performed. $^{20}$ Table 2 illustrates the base pair sequences of both primers.

\section{Polymerase Chain Reaction (Real-Time PCR)}

The presence of mecA and PVL was determined among all isolated strains of $S$. aureus; mecA and $P V L$ genes were analyzed by real-time PCR according to a specific condition (Table 2) that was programmed in the protocol by Bhatta et al, and PCR amplification and real-time hybridization were conducted using the Promega GoTaq ${ }^{\circledR}$ Probe qPCR Master Mix Kit (USA). Mastermix contains GoTaq $^{\circledR}$ Hot Start Polymerase, SYBR green dye, $\mathrm{MgCl}$, dNTPs, and a proprietary reaction buffer. DNA samples to be run in PCR were diluted to $10 \mathrm{ng} / \mu \mathrm{L} .{ }^{20}$

Multiplex conventional PCR was used for detection of $m e c A$ and $P V L$ for all isolated S. aureus strains (24) by using the same primer as in Table 1, but with different PCR conditions, programmed in the protocol by Bhatta et al (2016) and illustrated in Table 3.

\section{Gel Electrophoresis}

Agarose gel electrophoresis was prepared according to what was prepared previously. ${ }^{21}$ All PCR products were run on $1 \%$ agarose gel electrophoresis for 30 minutes and $100 \mathrm{bp}$ DNA ladder or marker was used for the validation of the length of the amplified PCR product. The gel image was visualized using UV light and photographed.

\section{Statistical Analysis}

All the data were analyzed using Microsoft Excel for statistical analysis. Mean, standard deviation, and chisquare tests were used to correlate different parameters, and Fischer exact tests were used to find significant values; $\mathrm{p}<0.05$ was used as a level of significance in this study.

\section{Results}

In this study, 46 swab samples from DFI were investigated. The participants were 29 males (63\%) and 17 females $(37 \%)$, with a male-to-female ratio of $1.7: 1$. The participant's age ranged from 41 to 82 years, with a mean of $57.4( \pm$ SD8.6). A majority of the samples were collected from outpatient clinics $(33 ; 71.7 \%)$, and the rest $(13 ; 28.3 \%)$ were from hospitalized patients.

Glucose control status was assessed; the mean HbA1c was $8.4 \%( \pm \mathrm{SD} 1.9)$, while the mean random blood sugar was $236.2 \mathrm{mg} / \mathrm{dl}$ ( \pm SD 102.3). According to the American Diabetes Association's general glycemic target, 34 patients (74\%) had HbA1c above the target (7\%), while $12(26 \%)$ had last HbAlc of $\leq 7 \%{ }^{1}$

Lower limb or foot amputation was observed in six participants (13\%), and 14 patients (30.5\%) had foot deformities. Smoking status, alcohol consumption, and previous antibiotic intake were illustrated in Table 4, and it is obvious that current smoking and alcohol consumption was less prevalent among participants.

Out of 46 swab samples, 43 (93.5\%) showed positive bacterial growth, while only three samples $(6.5 \%)$ were

Table 3 Multiplex PCR Conditions for Amplification of mecA and PVL

\begin{tabular}{|c|c|c|c|c|c|c|}
\hline Gene Cycles & Initial Denaturation & Denaturation & Annealing & Extension & Final Extension & \\
\hline Time and temperature mecA and $P V L$ gene & $95{ }^{\circ} \mathrm{C} / 5$ minutes & $94^{\circ} \mathrm{C} / 45$ seconds & $58^{\circ} \mathrm{C} / 45$ seconds & $72^{\circ} \mathrm{C} / 30$ seconds & $72^{\circ} \mathrm{C} / 5$ minutes & 30 \\
\hline
\end{tabular}


Table 4 Characteristics of the Study Participants

\begin{tabular}{|c|c|c|}
\hline \multicolumn{2}{|l|}{ Parameters } & \multirow{3}{*}{$\begin{array}{l}\text { Number (\%) } \\
29(63) \\
17(37)\end{array}$} \\
\hline Sex & Male & \\
\hline & Female & \\
\hline \multirow[t]{4}{*}{ Smoking and alcoholic status } & Smoker & $10(21.7)$ \\
\hline & Non-smoker & $36(78.3)$ \\
\hline & Alcohol intake & $2(4.3)$ \\
\hline & Non-alcoholic & $44(95.7)$ \\
\hline \multirow{3}{*}{$\begin{array}{l}\text { Amputations and deformed } \\
\text { foot appearance }\end{array}$} & Amputation & $6(13)$ \\
\hline & Deformed foot & $14(30.5)$ \\
\hline & Normal foot & $26(56.5)$ \\
\hline \multirow[t]{2}{*}{ Previous antibiotic treatment } & Yes & $14(30.4)$ \\
\hline & No & $32(69.6)$ \\
\hline \multirow[t]{2}{*}{ Sample source } & Outpatient clinic & $33(7 \mid .7)$ \\
\hline & $\begin{array}{l}\text { Hospitalized } \\
\text { patients }\end{array}$ & $13(28.3)$ \\
\hline \multirow[t]{2}{*}{$\mathrm{HbAlc}$} & $\mathrm{HbAlc} \leq 7 \%$ & $12(26)$ \\
\hline & $\mathrm{HbAlc}>7 \%$ & 34 (74) \\
\hline
\end{tabular}

found to be negative for bacterial growth. The relation between $\mathrm{HbAlc}$ and positive culture result was analyzed and found to be statistically insignificant.

Of 43 positive cultures, 31 samples $(72 \%)$ were from outpatient clinics and $12(28 \%)$ were from hospitalized patients. Of positive culture results, 23 patients $(53.5 \%)$ had monomicrobial growth and $20(46.5 \%)$ had more than one organism isolated from their lesions. Table 5 shows that most of the hospital isolates were monomicrobial and most of the community-based results were polymicrobial, but the difference was statistically insignificant.

A total of 62 bacteria were isolated according to colonial morphology from 43 growth-positive diabetic patients, resulting in an average of 1.4 organisms per sample. The results showed that Gram-positive organisms (36; 58\%) were more prevalent than Gram-negative organisms (26; 42\%).

The most common isolated species among Grampositive bacteria was Staphylococcus aureus (24; 38.7\%), based on colonial morphology on blood agar and mannitol salt agar. Among all 24 isolated Staphylococcus aureus strains, mixed infection was observed in nine $(37.5 \%)$, while $15(62.5 \%)$ were monomicrobial. The majority of $S$. aureus isolates were from outpatients $(17 ; 70.8 \%)$, while seven (29.2\%) were reported from hospitalized patients ( $p$ value: 0.0223 ). Table 6 illustrates the relation of this distribution to the culture result.

Antimicrobial susceptibility pattern was tested for all the 24 isolated $S$. aureus strains using the Kirby-Bauer disc diffusion method. The sensitivity was interpreted according to CLSI. ${ }^{19}$ The results were tested against 14 antimicrobial agents and expressed as a percentage of resistance or sensitivity to antimicrobial agents. Penicillin showed the highest resistance $(100 \%)$ among all the antimicrobial agents, followed by trimethoprim (66.6\%), azithromycin (58.3\%), and ciprofloxacin and tetracycline (54.2\% for each). The sensitivity was highest (100\%) to vancomycin, followed by rifampicin $(87.5 \%)$, gentamicin $(83.3 \%)$, and chloramphenicol (70.8\%). Table 7 illustrates all resistance and sensitivity patterns for all antimicrobial tests.

\section{Phenotypic Detection of MRSA}

Two tests were performed for MRSA detection: cefoxitin and oxacillin disc tests. The results showed that among all isolated $S$. aureus strains, 11 (45.8\%) were cefoxitin-resistant, while nine $(37.5 \%)$ were oxacillin-resistant, which was statistically significant ( $p$ value: 0.00 ). Table 8 demonstrates the distribution of cefoxitin and oxacillin disc diffusion tests among all isolated $S$. aureus strains.

\section{Genotypic Detection for mecA Gene and PVL Gene}

The MRSA gene $(m e c A)$ and virulence gene $(P V L)$ were tested by q-PCR, and the results were read by the microsoftware mic PCR program.

\section{mecA Gene Detection}

$m e c A$ was analyzed by q-PCR for all $S$. aureus isolates (24). Among all isolated strains, $10(41.6 \%)$ were positive for $m e c A$; Figure 1 illustrates positive results in the Amplification plot

Table 5 Distribution of Positive Growth Culture Among Community-Acquired Patients and Hospitalized Patients

\begin{tabular}{|l|l|l|l|}
\hline Source of Samples & Polymicrobial Infections & Monomicrobial Infection & Total \\
\hline Hospital-based & $2(16.6 \%)$ & $10(83.4 \%)$ & $12(28 \%)$ \\
Outpatients (community) & $18(58 \%)$ & $13(42 \%)$ & $31(72 \%)$ \\
Total & $20(46.5 \%)$ & $23(53.5 \%)$ & $43(100 \%)$ \\
\hline
\end{tabular}

Notes: Chi square: 5.95 ; p-value: 0.146 . 
Table 6 Distribution of S. aureus Among Hospitalized Patients and Community Patients

\begin{tabular}{|l|l|l|l|}
\hline S. aureus & $\begin{array}{l}\text { Hospitalized } \\
\text { Patient }\end{array}$ & $\begin{array}{l}\text { Outpatient } \\
\text { (Non- } \\
\text { Hospitalized) }\end{array}$ & Total \\
\hline Polymicrobial infections & $0(0 \%)$ & $9(37.5 \%)$ & $9(37.5 \%)$ \\
Monomicrobial infections & $\begin{array}{l}7(29 \%) \\
7(29 \%)\end{array}$ & $\begin{array}{l}8(33.3 \%) \\
17(71 \%)\end{array}$ & $\begin{array}{l}15(62.5 \%) \\
24(100 \%)\end{array}$ \\
Total & &
\end{tabular}

Note: $P$ value: 0.0223 .

Table 7 Antimicrobial Susceptibility Pattern of Clinical Staphylococcus aureus Isolated from Diabetic Foot Infections

\begin{tabular}{|l|l|l|l|}
\hline $\begin{array}{l}\text { Antimicrobial Agent } \\
(\boldsymbol{\mu} \text { g) }\end{array}$ & $\begin{array}{l}\text { Susceptible } \\
\mathbf{n}(\%)\end{array}$ & $\begin{array}{l}\text { Intermediate } \\
\mathbf{n}(\%)\end{array}$ & $\begin{array}{l}\text { Resistant } \\
\mathbf{n}(\%)\end{array}$ \\
\hline Vancomycin (30) & $24(100)$ & $0(0)$ & $0(0)$ \\
Penicillin (10) & $0(0)$ & $0(0)$ & $24(100)$ \\
Ciprofloxacin (10) & $8(33.3)$ & $3(12.5)$ & $13(54.2)$ \\
Rifampicin (5) & $21(87.5)$ & $0(0)$ & $3(12.5)$ \\
Clindamycin (10) & $12(50)$ & $1(4.16)$ & $11(45.8)$ \\
Gentamicin (10) & $20(83.3)$ & $1(4.16)$ & $3(12.5)$ \\
Azithromycin (15) & $8(33.3)$ & $2(8.33)$ & $14(58.3)$ \\
Erythromycin (10) & $10(41.6)$ & $5(20.8)$ & $9(37.5)$ \\
Tetracycline (10) & $11(45.8)$ & $0(0)$ & $13(54.2)$ \\
Chloramphenicol (30) & $17(70.8)$ & $1(4.16)$ & $6(25)$ \\
Trimethoprim (5) & $8(33.3)$ & $0(0)$ & $16(66.6)$ \\
Cefoxitin (30) & $13(54.2)$ & $0(0)$ & $1 \mathrm{I}(45.8)$ \\
Oxacillin (5) & $15(62.5)$ & $0(0)$ & $9(37.5)$ \\
Amoxicillin-clave acid (30) & $16(66.6)$ & $0(0)$ & $8(33.3)$ \\
\hline
\end{tabular}

Table 8 Cefoxitin and Oxacillin Disc Diffusion Tests

\begin{tabular}{|l|l|l|l|}
\hline $\begin{array}{l}\text { Phenotypic Disc } \\
\text { Test }\end{array}$ & $\begin{array}{l}\text { Cefoxitin } \\
\text { Susceptible }\end{array}$ & $\begin{array}{l}\text { Cefoxitin } \\
\text { Resistant }\end{array}$ & Total \\
\hline $\begin{array}{l}\text { Oxacillin susceptible } \\
\text { Oxacillin resistant }\end{array}$ & $\begin{array}{l}13(54.2 \%) \\
\text { Total }\end{array}$ & $2(8.3 \%)$ & $15(62.5 \%)$ \\
$13(54.2 \%)$ & $9(37.5 \%)$ & $9(37.5 \%)$ \\
Tl (45.8\%) & $24(100 \%)$ \\
\hline
\end{tabular}

Note: $P$ value: $<0.001$.

(green cycle). A majority of the $m e c A$-positive isolates were obtained from community patients $(60 \%)$, while the remaining $m e c A$-positive strains $(40 \%)$ were from hospitalized patients.

The sources of samples (hospitalized and community) among diabetic patients in relation to three methods used in diagnoses of MRSA were analyzed, and there was no relation between the test type and the source of the samples (Table 9).

\section{PVL Gene Detection}

$P V L$ was analyzed by q-PCR for all isolated strains of $S$. aureus (24), and none of the strains was found to be positive for this gene.

\section{Multiplex PCR for mecA and PVL Gene}

Both genes (mecA and $P V L$ ) were run in a multiplex PCR for all 24 isolated $S$. aureus strains. An amplification of the mecA gene showed a 310 bp fragment in $10(41.6 \%)$ samples; no positive results for $P V L$ were observed (Figure 2).

\section{Discussion}

DFI contributes significantly to morbidity and mortality, which can arise from uncontrolled blood sugar and poor self-care. ${ }^{22}$ Proper glycemic control is important for infection eradication and ulcer healing. ${ }^{23}$ Although our participants' mean glycemia, expressed as HbAlc, was not very high $(8.4 \%)$, a majority of participants with DFI had HbAlc above the general target level (>7\%). In line with previously conducted studies, the mean age of participants was 57.4, and most of the patients were men. ${ }^{24,25}$ The participants' lifestyles, professional activities, and jobs might lead to males being more prone to ulcer infection than females.

The microbiological profile of DFI is variable, and it depends on the acute or chronic character of the wound, duration of hospitalization, and previous antibiotic therapy. In this study, most of the diabetic foot ulcers were infected. Although history of antibiotic use was reported for all patients, some patients might not have remembered what medication they took, as there is no medical record in our locality. Similar to Akhi et al (2017), ${ }^{26}$ the mean number of isolates in this study was 1.4 aerobic bacteria per sample. Our results revealed that more than half of specimens yielded a single isolate, which is in line with Viquez-Molina et al (2018) ${ }^{27}$ but differs from studies that observed a greater proportion of polymicrobial infection. $^{28,29}$ The polymicrobial etiology of DFI may be due to depressed immunity in individuals, and poor vascular supply to the feet and chronicity of the wound, which may be contaminated by community-type bacteria and microbial flora. The high prevalence of monomicrobial infections and relatively low rate of isolated pathogens per lesion in this study may be attributable to less severe wound infections.

In agreement with numerous studies, Staphylococcus aureus is the main causative pathogen in diabetic foot ulcer, as we observed $S$. aureus in $38.7 \%$ of the participants. Many studies have exhibited a high prevalence of Gram-positive bacteria in DFI. ${ }^{25,30}$ Indeed, S. aureus is 


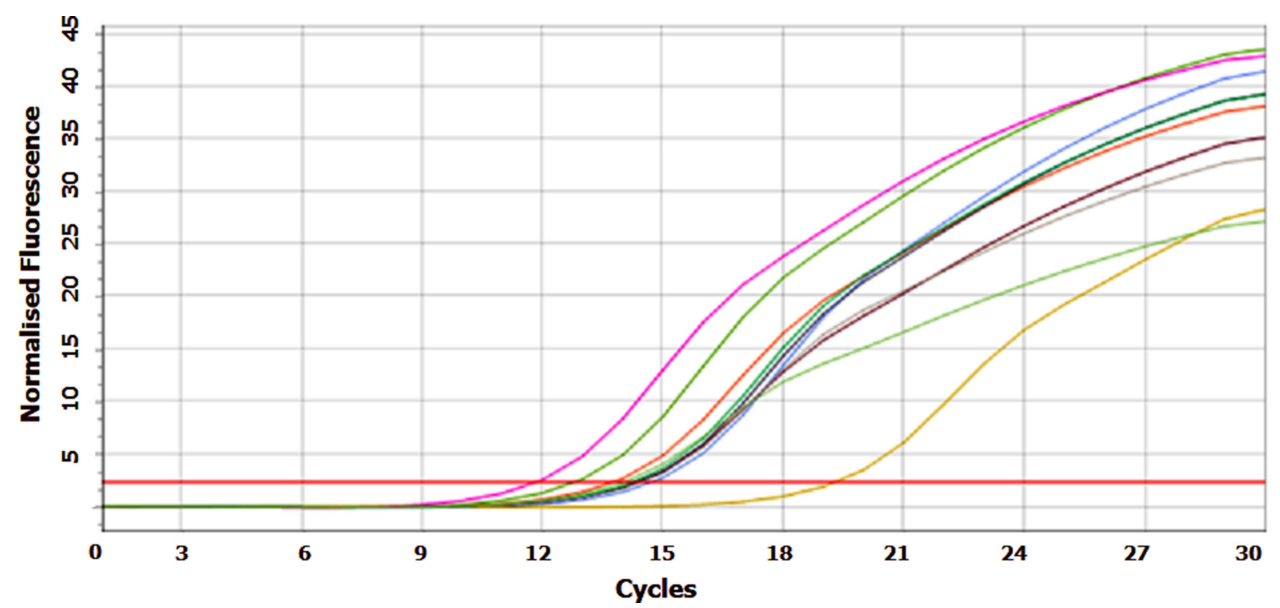

Figure I Amplification plot of mecA gene (green cycle).

normal flora of the skin and is the most important true pathogen of skin infections in general. By contrast, other studies have recovered Gram-negative bacteria, Enterobacteriaceae such as E. coli, Proteus spp., and anaerobic bacteria. ${ }^{28,31}$

The antimicrobial susceptibility test is a useful guide for prescribing appropriate antibiotics for DFI. Resistance to antibiotics is associated with an increased period of hospitalization, high mortality, and increased treatment costs, including a need for alternative medications. ${ }^{32}$ The initial management of DFI comprises empirical antimicrobial treatment based on the susceptibility data. ${ }^{13}$ In this study, antibiotic susceptibility was investigated for all the isolated $S$. aureus using the KirbyBauer disc diffusion method; all $S$. aureus strains were susceptible to vancomycin, which is in agreement with previous studies. ${ }^{26,29,31-33}$ Undeniably, vancomycin-resistant $S$. aureus strain was rarely reported. ${ }^{34}$ Thus, the antibiotic vancomycin was found to be highly effective against Gram-positive organisms, and it still remains the drug of choice for serious infections.

In the current study, the susceptibility of $S$. aureus to rifampicin, gentamicin, and chloramphenicol was $87.5 \%$, $83.3 \%$, and $70.8 \%$, respectively, meaning that these

Table 9 MRSA Among Hospitalized and Community Patient Comparison of Phenotypic and Genotypic Methods for the Detection of MRSA

\begin{tabular}{|l|l|l|l|}
\hline S. aureus & $\begin{array}{l}\text { mecA Gene } \\
\text { Positive }\end{array}$ & $\begin{array}{l}\text { Oxacillin } \\
\text { Positive }\end{array}$ & $\begin{array}{l}\text { Cefoxitin } \\
\text { Positive }\end{array}$ \\
\hline Hospitalized patient & $4(40 \%)$ & $3(33.3 \%)$ & $4(36.4 \%)$ \\
Community patient & $6(60 \%)$ & $6(66.7 \%)$ & $7(63.6 \%)$ \\
Total & $10(100 \%)$ & $9(100 \%)$ & $11(100 \%)$ \\
\hline
\end{tabular}

Notes: Chi-square test: $0.0913 ; P$ value: 0.955 .

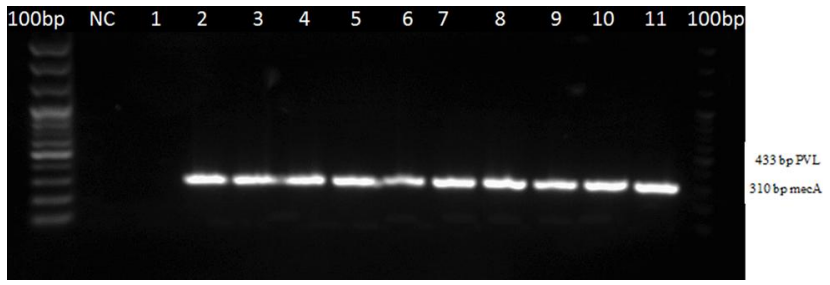

Figure 2 Multiplex PCR of mecA and PVL genes.

Notes: 100bp DNA ladder; NC, negative control; Lane I, negative sample for mecA and PVL genes; Lane 2-II, samples with positive for mecA gene and negative for PVL gene.

antibiotics are effective in vitro against $S$. aureus isolates, as observed by previous studies. ${ }^{26,31,32}$ Consistently with other studies, we noticed that more than half of the isolated $S$. aureus were found to be resistant to tetracycline. ${ }^{31}$ We also noticed that all isolated $S$. aureus were resistant to penicillin; however, penicillin-sensitive $S$. aureus was infrequently reported. ${ }^{34}$ Our results further justified the inappropriateness of penicillin as a treatment option for Staphylococcus aureus infection. It has been revealed that more than $40 \%$ of the isolated Staphylococcus aureus from DFI were MRSA; therefore, rapid and accurate detection of MRSA is of major importance for the appropriate clinical management of DFI, including both hospital- and community-based types. ${ }^{26}$

In the last decade, there have been many attempts by international guidelines such as CLSI to improve and standardize specific phenotypic methods (cefoxitin and oxacillin disc diffusion) for the detection of MRSA. ${ }^{35}$ However, these two tests are less popularly used by medical laboratories in this region due to less experienced medical staff. In the current study, $45.8 \%$ of the isolated S. aureus strains were cefoxitin-resistant, while $37.5 \%$ were resistant to oxacillin disc. All the oxacillin-resistant 
strains were resistant to cefoxitin. These observations were comparable to studies that recorded the same effectiveness of the cefoxitin disc test as a standard phenotypic method. $^{34}$

In spite of phenotypic diagnosis, nowadays detection of $m e c A$ also plays an important role in confirming MRSA. Detection of $m e c A$ by real-time PCR to determine MRSA has been considered the standard method because of its accuracy and reproducibility. ${ }^{36}$ In this study, $41.6 \%$ of the isolated $S$. aureus strains were positive for mecA. Although a single isolate was phenotypically resistant to cefoxitin, it did not show amplification of mecA that might carry another gene, such as $m e c C$, instead of $m e c A .{ }^{37}$ In contrast to this result, mec $A$ was reported among cefoxitinsensitive strains. ${ }^{33}$ This variation between the phenotypic and genotypic methods may be related to culture settings, temperature, configuration of culture medium, size of inocula, time of incubation, and manual skill of medical staff. $^{38}$

According to the oxacillin disc test, two oxacillinsusceptible strains carried mecA and one oxacillinresistant strain was negative for $m e c A$. This finding may suggest that it is better to use the cefoxitin disc rather than the oxacillin disc test. It has been suggested that the efficacy of the cefoxitin test is superior to that of the oxacillin test and that it sometimes can be used as an alternative to PCR. ${ }^{39}$ The phenotypic methods of MRSA identification are time-consuming and have their limitations in terms of generating false-positive and falsenegative results leading to delay or ineffective antibiotic prescriptions; however, they are still commonly used because of the unavailability and high cost of PCR materials and few experienced staff to carry out PCR techniques.

One of the factors that plays a role in the pathogenicity of Staphylococcus aureus and leads to excess inflammatory responses, tissue damage, and eventually overcoming the host immune response is the presence of $P V L .^{40}$ However, $P V L$ is less frequently prevalent globally with significant variation in its prevalence among geographical areas $(5 \%$ in France; $4.9 \%$ in the UK). ${ }^{7}$ In this study, the analysis of $P V L$ was negative, even using conventional and real-time PCR procedure. $P V L$-negative results were consistently recorded in Poland and Portugal. ${ }^{33,41}$ It has also been suggested that $P V L$-positive strains are less frequently detected among DFI. ${ }^{7}$ Another reason may be the small sample size in our study, and some specimens were obtained from hospital sources, as this gene is mostly prevalent in community species.
We reached the conclusion that accurate detection of the causative agents of DFI is the key step in prescribing effective antibiotics so as to encourage wound healing and minimize subsequent complications. Staphylococcus aureus is the predominant pathogen in DFI. Cefoxitin disc diffusion appears to be a widely available and accurate phenotypic method for MRSA detection and can be helpful in addressing the popularity of resistance pathogens. Indeed, genotypic methods can accurately identify MRSA and its potentially responsible virulent genes; however, PCR is costly, and its use requires special skills. We could not find significant differences between conventional PCR and real-time PCR for mecA detection.

Further studies are recommended and should include samples from different levels of skin lesions in large numbers of patients and analyze virulent factors. It is suggested that the SCCmecA gene be specified, both in community- and hospital-acquired MRSA strains. Analysis of further genes, such as mecC, is needed for strains with positive phenotypic MRSA.

\section{Abbreviations}

BMI, body mass index; CLSI, Clinical Laboratory Standards Institute; DFI, diabetic foot infection; FPG, fasting plasma glucose; HbA1c, hemoglobin A1c; MRSA, methicillinresistant Staphylococcus aureus; MSSA, methicillinsensitive Staphylococcus aureus; PBPs, penicillin-binding proteins; PCR, polymerase chain reaction; PVL, PantonValentine leukocidin.

\section{Data and Resource Availability}

The datasets generated and analyzed during the current study are available from the corresponding author (J.M, email: jamal.salih@univsul.edu.iq) upon reasonable request.

\section{Acknowledgment}

We would like to thank all the mentioned hospitals and centers from which we collected our study samples.

\section{Funding}

This research did not receive any specific grant from funding agencies in the public, commercial, or not-forprofit sectors. There is no prior presentation of this research work.

\section{Disclosure}

The authors declare there are no conflicts of interest to disclose. 


\section{References}

1. Inzucchi SE, Bergenstal RM, Buse JB, et al. Management of hyperglycemia in type 2 diabetes, 2015: a patient-centered approach: update to a position statement of the American Diabetes Association and the European Association for the Study of Diabetes. Diab Care. 2015;38(1):140-149. doi:10.2337/dc14-2441

2. Hinojosa CA, Boyer-Duck E, Anaya-Ayala JE, et al. Impact of the bacteriology of diabetic foot ulcers in limb loss. Wound Repair Regeneration. 2016;24(5):923-927.

3. Uckay I, Aragon-Sanchez J, Lew D, Lipsky BA. Diabetic foot infections: what have we learned in the last 30 years? Int $J$ Infectious Diseases. 2015;40:81-91. doi:10.1016/j.ijid.2015.09.023

4. Karmaker M, Sanyal SK, Sultana M, Hossain M. Association of bacteria in diabetic and non-diabetic foot infection-An investigation in patients from Bangladesh. J Infect Public Health. 2016;9 (3):267-277. doi:10.1016/j.jiph.2015.10.011

5. Nicoleta M, Gheorghe I, Popa M, et al. Phenotypic and genotypic investigation of resistance and virulence features of methicillin resistant Staphylococcus aureus strains isolated from hospitalized patients. Romanian Biotechnological Letters. 2016;21(3):11591.

6. Malachowa N, DeLeo FR. Mobile genetic elements of Staphylococcus aureus. Cellular Molecular Life Sci. 2010;67 (18):3057-3071.

7. Dunyach-Remy C, Ngba Essebe C, Sotto A, Lavigne J-P. Staphylococcus aureus toxins and diabetic foot ulcers: role in pathogenesis and interest in diagnosis. Toxins. 2016;8(7):209. doi:10.3390/ toxins 8070209

8. Bhutia KO, Singh TS, Biswas S, Adhikari L. Evaluation of phenotypic with genotypic methods for species identification and detection of methicillin resistant in Staphylococcus aureus. Int J Appl Basic Med Res. 2012;2(2):84. doi:10.4103/2229-516X.106348

9. Boudreau MA, Fishovitz J, Llarrull LI, Xiao Q, Mobashery S. Phosphorylation of BlaR1 in manifestation of antibiotic resistance in methicillin-resistant Staphylococcus aureus and its abrogation by small molecules. ACS Infectious Diseases. 2015;1(10):454-459. doi:10.1021/acsinfecdis.5b00086

10. Wang F, Zhou H, Olademehin OP, Kim SJ, Tao P. Insights into key interactions between vancomycin and bacterial cell wall structures. ACS Omega. 2018;3(1):37-45. doi:10.1021/acsomega.7b01483

11. Gould IM, David MZ, Esposito S, et al. New insights into meticillin-resistant Staphylococcus aureus (MRSA) pathogenesis, treatment and resistance. Int $J$ Antimicrob Agents. 2012;39 (2):96-104. doi:10.1016/j.ijantimicag.2011.09.028

12. Telles JP, Cieslinski J, Tuon FF. Daptomycin to bone and joint infections and prosthesis joint infections: a systematic review. Brazilian J Infectious Diseases. 2019;23:191-196. doi:10.1016/j. bjid.2019.05.006

13. Lipsky BA, Aragón-Sánchez J, Diggle M, et al. IWGDF guidance on the diagnosis and management of foot infections in persons with diabetes. Diabetes Metab Res Rev. 2016;32:45-74.

14. Gosset P, Pichavant M, Sirard J-C, Bachirou K, Perez-cruz M Methods and pharmaceutical compositions for the treatment of acute exacerbations of chronic obstructive pulmonary disease. Google Patents; 2018.

15. Wang S-H, Sun Z-L, Guo Y-J, et al. Meticillin-resistant Staphylococcus aureus isolated from foot ulcers in diabetic patients in a Chinese care hospital: risk factors for infection and prevalence. $J$ Med Microbiol. 2010;59(10):1219-1224. doi:10.1099/ jmm.0.020537-0

16. Nelson EA, Backhouse MR, Bhogal MS, et al. Concordance in diabetic foot ulcer infection. BMJ Open. 2013;3(1).

17. Mathangi T, Prabhakaran P, Rayappan F, Tilton F. Isolation, molecular characterization and antibiogram of bacteria isolated from diabetic foot ulcers. Int J Curr Res Aca Rev. 2013;1(1):17-25.
18. Sastry AS, Bhat S. Essentials of Medical Microbiology. Jaypee Brothers, Medical Publishers Pvt. Limited; 2018.

19. CLSI. M100 Performance Standards for Susceptibility Testing. Clinical and Laboratory Standards Institute Wayne (PA); 2018.

20. Karmakar A, Jana D, Dutta K, Dua P, Ghosh C. Prevalence of panton-valentine leukocidin gene among community acquired Staphylococcus aureus: a real-time PCR study. J Pathog. 2018;2018.

21. Bhatta DR, Cavaco LM, Nath G, et al. Association of Panton Valentine Leukocidin (PVL) genes with methicillin resistant Staphylococcus aureus (MRSA) in Western Nepal: a matter of concern for community infections (a hospital based prospective study). BMC Infect Dis. 2016;16(1):199. doi:10.1186/s12879-016-1531-1

22. Karadağ FY, Saltoğlu N, Ö A, et al. Foot self-care in diabetes mellitus: evaluation of patient awareness. Prim Care Diabetes. 2019.

23. Verrone Quilici MT, Del Fiol F, Franzin VAE, Toledo MI. Risk factors for foot amputation in patients hospitalized for diabetic foot infection. J Diab Res. 2016;2016.

24. Abdul Qadir D, Ali SAAA, Mahmoud HM. Prevalence of bacterial types in Wagner grade three of diabetic foot ulcer. Iraqi $J$ Sci. 2014;55(3B):1232-1235.

25. Anvarinejad M, Pouladfar G, Japoni A, et al. Isolation and antibiotic susceptibility of the microorganisms isolated from diabetic foot infections in Nemazee Hospital, Southern Iran. $J$ Pathog. $2015 ; 2015$.

26. Akhi MT, Ghotaslou R, Memar MY, et al. Frequency of MRSA in diabetic foot infections. Int J Diab Dev Ctries. 2017;37(1):58-62. doi:10.1007/s13410-016-0492-7

27. Víquez-Molina G, Aragón-Sánchez J, Pérez-Corrales C, MurilloVargas C, López-Valverde ME, Lipsky BA. Virulence factor genes in Staphylococcus aureus isolated from diabetic foot soft tissue and bone infections. Int $J$ Low Extrem Wounds. 2018;17(1):36-41. doi: $10.1177 / 1534734618764237$

28. Katz DE, Friedman ND, Ostrovski E, et al. Diabetic foot infection in hospitalized adults. $J$ Infection Chemotherapy. 2016;22(3):167-173. doi:10.1016/j.jiac.2015.12.007

29. Dwedar R, Ismail DK, Abdulbaky A. Diabetic foot infection: microbiological causes with special reference to their antibiotic resistance pattern. Egyptian J Med Microbiol. 2015;38(3174):1-8.

30. Citron DM, Goldstein EJ, Merriam CV, Lipsky BA, Abramson MA. Bacteriology of moderate-to-severe diabetic foot infections and in vitro activity of antimicrobial agents. $J$ Clin Microbiol. 2007;45 (9):2819-2828. doi:10.1128/JCM.00551-07

31. Hatipoglu M, Mutluoglu M, Turhan V, et al. Causative pathogens and antibiotic resistance in diabetic foot infections: a prospective multi-center study. J Diab Complications. 2016;30(5):910-916. doi:10.1016/j.jdiacomp.2016.02.013

32. Kim TG, Moon SY, Park MS, et al. Factors affecting length of hospital stay and mortality in infected diabetic foot ulcers undergoing surgical drainage without major amputation. J Korean Med Sci. 2016;31(1):120-124. doi:10.3346/jkms.2016.31.1.120

33. Mottola C, Semedo-Lemsaddek T, Mendes JJ, et al. Molecular typing, virulence traits and antimicrobial resistance of diabetic foot staphylococci. J Biomed Sci. 2016;23(1):33. doi:10.1186/s12929016-0250-7

34. Perim MC, Borges J, Celeste SRC, et al. Aerobic bacterial profile and antibiotic resistance in patients with diabetic foot infections. Rev Soc Bras Med Trop. 2015;48(5):546-554. doi:10.1590/0037-8682-01462015

35. Clinical, Institute LS. Performance Standards for Antimicrobial Susceptibility Testing; 17th Informational Supplement. Wayne, PA, USA: CLSI document M100-S17 Clinical and Laboratory Standards Institute; 2007.

36. Baddour M, AbuElKheir M, Fatani A. Comparison of mecA polymerase chain reaction with phenotypic methods for the detection of methicillin-resistant Staphylococcus aureus. Curr Microbiol. 2007;55 (6):473. doi:10.1007/s00284-007-9015-6 
37. Deplano A, Vandendriessche S, Nonhoff C, Denis O. Genetic diversity among methicillin-resistant Staphylococcus aureus isolates carrying the mecC gene in Belgium. J Antimicrobial Chemotherapy. 2014;69(6):1457-1460. doi:10.1093/jac/dku020

38. Kavitha Y, Mohan S, Moinuddin SK. Bacteriological profile of diabetic foot infection with special reference to ESBL and MRSA in a coastal tertiary care teaching hospital. Indian $J$ Microbiol Res. 2017;4(1):68-73

39. Demir T, Coplu N, Esen B. Comparative analysis of phenotypic and genotypic detection of methicillin resistance among Staphylococcus aureus. Indian J Pathol Microbiol. 2016;59(3):314. doi:10.4103/ 0377-4929.188103
40. Stappers MH, Hagen F, Reimnitz P, Mouton JW, Meis JF, Gyssens IC. Direct molecular versus culture-based assessment of Gram-positive cocci in biopsies of patients with major abscesses and diabetic foot infections. European J Clin Microbiol Infectious Diseases. 2015;34(9):1885-1892. doi:10.1007/s10096-015-2428-4

41. Pobiega M, Myjak I, Pomorska-Wesolowska M, et al. Virulence potential of Staphylococcus aureus strains isolated from diabetic foot ulcers among patients from southern Poland. Curr Vasc Pharmacol. 2016;14(6):547-551. doi:10.2174/1570161114666160 625083742

\section{Publish your work in this journal}

The International Journal of General Medicine is an international, peer-reviewed open-access journal that focuses on general and internal medicine, pathogenesis, epidemiology, diagnosis, monitoring and treatment protocols. The journal is characterized by the rapid reporting of reviews, original research and clinical studies across all disease areas. The manuscript management system is completely online and includes a very quick and fair peer-review system, which is all easy to use. Visit http://www.dovepress.com/ testimonials.php to read real quotes from published authors.

Submit your manuscript here: https://www.dovepress.com/international-journal-of-general-medicine-journal 